アマサギ (Bubulcus ibis coromandus) 北海道大沼に渡来

森口和 明*

The Record of the Cattle Egret, Bubulcus ibis coromandus

Sighted in Onuma, Hokkaido.

The bird is very rare in Hokkaido.

Kazuaki MORIGUCHI*

1. はじめに

1973 年 5 月 9 日, 南北海道大沼に扔いて鳥類調査中, 沼の湿地帯にてアマサギ (Bubulcus ibis coromandus) 2 羽を観察する機会を得た。本種は本道への渡来は数が 少ないので観察状況を報告する。

\section{2. 観察状況}

観察日時: 1973 年 5 月 9 日, 9 時 12 時

$$
\text { " } 5 \text { 月10日 }
$$

場 所: 北海道大沼の中, 小沼の畔, 湿地带

個 体 数: 2 羽

観 察 者: 森口和明, 10 日は助手 千春と 2 名。 観察方法および用具: 25 倍スコープ。9 倍双眼鏡。警 戒心を起こさせないため約 $60 \mathrm{~m}$ の地点の物陰より観 察。200 600 mm のズームレンズにて撮影した。写 真はスライドから反転焼付した。
型 態: サギ型。

体 色: 夏羽。1 羽は羽冠, 胸部背の飾羽はキツネ色 で謈いが, 他の 1 羽はキツネ色の部分は淡色であっ た。

行 動: 水深 $10 \mathrm{~cm}$ 位のところでドジョウを捕える のを観察したが, 頭を固定し餌物を注視し, 体のみ蛇 行させ突刺す様にしてドジョウをはさんだ。吞込むま でには 1 分も時間をかけていた。タニシ等をとる場合 には拾ら様にしていた。

なお繁殖を期待していたが, 11 日・16 日にも観察出 来なかった。

参考文献

小林桂助, 1966: 原色日本鳥類図鑑

日本鳥類保護連盟，1971：鳥類図鑑

(Received Sept. 7, 1973)

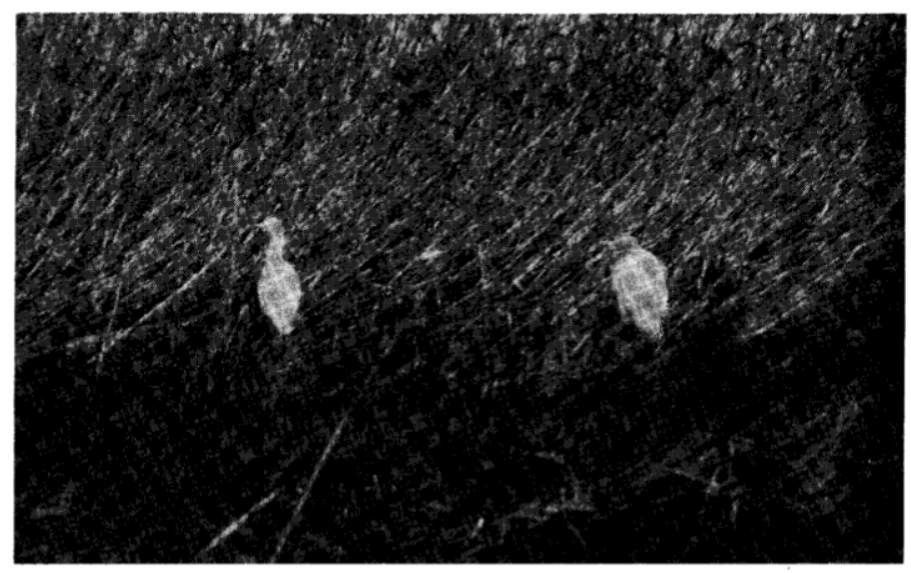

* 北海道函館市新川町 6-1

* 6-1, Shinkawacho, Hakodate, Hokkaido 